\title{
PENGARUH KECEMASAN BELAJAR DAN PEMAHAMAN KONSEP MATEMATIKA SISWA TERHADAP KEMAMPUAN PENALARAN MATEMATIKA
}

\author{
MUNASIAH \\ 13munasiah@gmail.com \\ Program Studi Teknik Informatika, Fakultas Teknik, Matematika, dan IPA \\ Universitas Indraprasta PGRI
}

\begin{abstract}
Abstrak. Penelitian ini dilakukan dengan tujuan mengetahui pengaruh kecemasan belajar dan pemahaman konsep matematika siswa terhadap kemampuan penanalaran matematika siswa. Hipotesis penelitian ini meliputi: 1) Terdapat pengaruh langsung yang signifikan kecemasan belajar terhadap kemampuan penalaran matematika. 2) Terdapat pengaruh langsung yang signifikan pemahaman konsep matematika siswa terhadap kemampuan penalaran matematika. 3) Terdapat pengaruh langsung yang signifikan kecemasan belajar terhadap pemahaman konsep matematika siswa. 4) Terdapat pengaruh tidak langsung yang signifikan kecemasan belajar terhadap kemampuan penalaran matematika melalui pemahaman konsep matematika siswa. Metode yang digunakan dalam penelitian ini adalah metode survey. Populasi terjangkau adalah siswa siswi kelas VIII tahun ajaran 2014/2015SMP swasta di Kota Depok. Besar sampel sebanyak 80 siswa, dengan teknik sampling yang digunakan adalah multistage sampling, diambil 4 sekolah swasta. Instrument penelitian yang digunakan yaitu angket kecemasan belajar sebanyak 25 pernyataan, tes pemahaman konsep matematika berbentuk pilihan ganda sebanyak 23 soal, tes kemampuan penalaran matematika berbentuk essay sebanyak 10 soal, yang te;ah diuji validitasnya. Analisis data menggunakan analisis jalur. Hasil pengujian hipotesis menunjukkan bahwa: 1) Terdapat pengaruh langsung yang tidak signifikan kecemasan belajar terhadap kemampuan penalaran matematika, 2) Terdapat pengaruh langsung yang signifikan pemahaman konsep matematika terhadap kemampuan penalaran matematika, 3) Terdapat pengaruh langsung yang tidak signifikan kecemasan belajar terhadap pemahaman konsep matematika, 4) Terdapat pengaruh tidak langsung yang tidak signifikan kecemasan belajar terhadap kemampuan penalaran matematika.
\end{abstract}

Kata kunci: kecemasan belajar, konsep matematika, penalaran matematika

\begin{abstract}
This research was conducted in order to know the influence of the anxiety of learning and students' understanding of mathematical concepts penanalaran mathematical abilities of students. The hypothesis of this study include: 1) There is a significant direct effect on the ability of anxiety learn mathematical reasoning. 2) There is significant direct influence students' understanding of mathematical concepts of mathematical reasoning abilities. 3) There is a significant direct effect of anxiety learn to understanding math concepts students. 4) There is a significant indirect effect on the ability of anxiety learn mathematical reasoning through the understanding of math concepts students. The method used in this research is survey method. Affordable population is class VIII students of academic year 2014/2015 a private SMP in Depok. A large sample of 80 students, with a sampling technique used was multistage sampling, taken four private schools. Research instrument used is questionnaire anxiety to learn as much as 25 statement, test understanding of mathematical concepts as much as 23 multiple choice questions, tests of mathematical reasoning ability in the form of an essay as much as 10 questions, which te; ah tested its validity. Analysis of data using path analysis. Hypothesis testing results show that: 1) There is a direct effect not significant anxiety
\end{abstract}


study on the ability of mathematical reasoning, 2) There is a direct effect of significant understanding of the mathematical concept of the ability of mathematical reasoning, 3) There is a direct effect not significant anxiety learn to understanding of mathematical concepts , 4) There is the indirect effect which is not significant anxiety on the ability to learn mathematical reasoning.

Keywords: anxiety of learning , mathematical concepts , mathematical reasoning

\section{PENDAHULUAN}

Pendidikan adalah usaha sadar dan terencana untuk mewujudkan suasana belajar dan proses pembelajaran agar peserta didik secara aktif mengembangkan potensi dirinya untuk memiliki kekuatan spiritual keagamaan, pengendalian diri, kepribadian, kecerdasan, akhlak mulia, serta keterampilan yang diperlukan dirinya, masyarakat, bangsa dan negara. Sehingga dalam melaksanankan pripsip penyelenggaraan pendidikan harus sesuai dengan tujuan pendiidkan nasional yaitu mencerdaskan kehidupan bangsa dan mengembangkan manusia Indoensia seutuhnya, yaitu manusia yang beriman dan bertaqwa terhadap Tuhan Yang Maha Esa dan berbudi pekerti luhur, memiliki pengetahuan dan keterampilan, kesehatan jasmani dan rohani, kepribadian yang mantap dan mandiri serta rasa tanggung jawab kemasyarakatan dan kebangsaan.

Pendidikan merupakan salah satu aspek dalam kehidupan yang memegang peranan penting. Suatu negara dapat mencapai sebuah kemajuan dalam teknologinya, jika pendidikan dalam negara berkualiatas baik. Tinggi rendahnya kualitas pendidikan, baik pendidikan formal maupun nonformal dalam suatu negara dipegaruhi oleh banyak faktor. Faktor yang memengaruhi pendidikan formal yang berada di sekolah bisa berasal dari peserta didik, tenaga pendidik, sarana prasarana, dan bisa juga karena faktor lingkungan.

Faktor yang memengaruhi belajar siswa baik pada pendidikan formal maupun non formal bisa berasal dari faktor intern dan faktor ekstern. Faktor intern adalah faktor yang ada dalam individu yang sedang belajar yaitu faktor jasmani (kesetahan, cacat tubuh), faktor psikologis (intelegensi, perhatian, minat, bakat, motif, kematanganan, kesiapan dan lain sebagainya), dan faktor kelelahan siswa (Slameto:, 2010:54). Faktor ekstern adalah faktor yang ada diluar individu yaitu faktor keluarga (cara orang tua mendidik, suasana rumah, keadaan ekonomi keluarga, pengertian orang tua dan lain-lain), faktor sekolah (metode mengajar, kurikulum, relasi guru dengan siswa, disiplin sekolah, sarana dan prasarana dan sebagainya), faktor masyarakat (kegiatan siswa dalam masyarakat, mass media, teman bergaul, bentuk kehidupan masyarakat dan lain-lain (Slameto, 2010:60).

Berpikir logis adalah suatu proses berpikir menggunakan logika, rasional, dan masuk akal. Dengan berpikir logis, kita akan mampu membedakan dan mengkritisi kejadian-kejadian yang terjadi pada saat ini apakah kejadian-kejadian itu masuk akal dan sesuai dengan ilmu pengetahuan atau tidak. Mata pelajaran di sekolah yang dapat mengajarkan siswa untuk berpikir kritis dan logis salah satunya adalah matematika. Matematika merupkaan ilmu yang mempunyai ciri-ciri khusus, salah satunya adalah penalaran dalam matematika yang bersifat deduktif aksiomatis yang berkenaan dengan ide-ide, konsep-konsep, dan simbol-simbol yang abstrak serta tersusun secara hierarkis. Materi matematika dan penalaran matematika merupakan dua hal yang tidak dapat dipisahkan, yaitu materi matematika dipahami oleh penalaran, dan penalaran dipahami dan dilatihkan melalui belajar materi matematika, sehingga kemampuan penalaran matematis sangat penting dan dibutuhkan dalam mempelajari matematika. Siswa yang mempunyai kemampuan penalaran tinggi antara lain tampak dari kemampuan berpikir 
secara logis, baik yang bersifat deduktif maupun induktif. Misalnya dalam menyelesaiakn soal-soal pelajaran matematika siswa mampu mengemukakan konsep-konsep yang mendasari penyelesaian soal. Selain itu, siswa mampu berpikir analitik, yaitu, suatu kegiatan berpikir berdasarkan langkah-langkah tertentu. Siswa mampu membuktikan teorema tertentu serta mampu menarik kesimpulan berdasarkan langkakh-langakah yang benar, misalnya dengan induksi matematik.

Siswa yang mempunyai kemampuan penalaran tinggi juga mampu menghubungkan benda nyata, gambar maupun soal-soal cerita ke dalam ide matematika dan menjelaskan ide matematika baik lisan maupun tulisan. Salah satu faktor yang menyebabkan matematika terasa sulit untuk siswa adalah keabstrakan matematika, sehingga siswa sulit untuk membayangkan apa yang sedang mereka pelajari. Kesulitan dalam belajara matematika disebabkan karena kebanyakan dari mereka hanya sekedar menghafalkan rumusnya bukan memahami konsepnya. Oleh karena itu, agar siswa dapat memahami materi pelajaran matematika, siswa perlu ditekankan pada pemahaman konsep dan penalaran matematika dari materi yang sedang dipelajari.

Kurikulum 2013 mengamanatkan esensi pendekatan ilmiah (saintifik) dalam pembelajaran. Pendekatan Ilmiah diyakini mampu mengembangkan ranah sikap, keterampilan dan pengetahuan peserta didik. Penilaian pembelajaran mencakup sikap, ketrampilan dan pengetahuan, ketiga-tiganya harus tuntas. Pada kenyataannya karena penyesuaiaan kurikulum baru, sekolah-sekolah di Indonesia belum seluruhnya menerapkan kurikulum 2013, yang mengamanatkan pembelajaran dengan pendekatan saintifik. Pembelajaran dengan pendekatan saintifik yaitu proses pembelajaran yang dirancang sedemikian rupa agar peserta didik secara aktif mengkonstruksi pengetahuan, ketrampilan, dan lainnya melalui tahapan mengamati, menanya, menalar, mencoba, dan membentuk jejaring untuk semua mata pelajaran. Pembelajaran matematika pada saat ini masih cenderung menggunakan pendekatan konvensional dimana seorang guru dianggap sebaga sumber ilmu, guru bertindak otoriter dan mendominasi kelas. Guru langsung mengajar matematika, membuktikan semua dalil-dalilnya dan memberikan contohcontohnya. Sebaliknya murid harus duduk dengan rapi, mendengarkan dengan tenang dan berusaha meniru cara-cara guru membuktikan dalil dan cara guru mengerjakan soal-soal. Peserta didik juga kurang diberikan kesempatan untuk berinisiatif, mencari jawaban sendiri, merumuskan dalil-dalil. Pada pembelajaran konvensional (teacher centered) guru hanya sekedar penyampai pesan, sementara siswa cenderung sebeagai penerima pengetahuan semata, guru juga lebih menekankan pada keterampilan berhitung daripada pengusaan konsep matematika. Akibatnya keterampilan berpikir tinggi seperti kemampuan penalaran matematika kurang berkembang. Pada dasarnya kemampuan penalaran matematika dipengaruhi oleh beberapa faktor, diantaranya minat siswa terhadap pelajaran Matematika, motivasi siswa, kebiasaan belajar siswa, kemandirian belajar, kecemasan siswa dalam belajar, dan pemahaman konsep matematika, selain faktor-faktor eksternal lainnya.

Kecemasan adalah suatu pengalaman subjektif mengenai ketegangan mental yang menggelisahkan sebagai reaksi umum dan ketidakmampuan menghadapi masalah atau adanya rasa aman. Perasaan yang tidak menyenagkan ini umumnya menimbulkan gejalagejala fisiologis (seperti gemetar, berkeringat, detak jantung meningkat, dan lain-lain) dan gejala-gejala psikologis (seperti panik, tegang, bingung, tidak dapat berkonsentrasi, dan sebagainya). Kecemasan adalah salah satu alasan mengapa hubungan interpersonal yang baik penting dalam memahami matematika. Kecemasan tersebut dapat meningkat dan memengaruhi sulit atau tidaknya pemahaman konsep.

Pemahaman konsep matematika siswa adalah ketika siswa mengerti sesuatu, mereka dapat menjelaskan konsep-konsep dalam kalimat mereka sendiri, menggunakan 
informasi dengan tepat dalam konteks baru, membuat analogi baru, dan generalisasi. Pemahaman konsep merupakan dasar dari pemahaman prinsip dan teori teori, sehingga untuk memahami prinsip dan teori terlebih dahulu siswa harus memahami konsep-konsep yang menyusun prinsip dan teori tersebut. Karena itu hal yang sangat fatal apabila siswa tidak memahami konsep-konsep matematika, jika mereka ingin menguasai matematika khususnya kemampuan berpikir tingkat tinggi siswa antara lain penalaran matematika. Berdasarkan paparan di atas, maka penulis merasa perlu meneliti tentang pengaruh kecemasan belajar dan pemahaman konsep matematika terhadap kemampuan penalaran matematika siswa.

\section{TINJAUAN PUSTAKA}

\section{Kemampuan Penalaran Matematika}

Robbins (2006:46) menyatakan bahwa, "Kemampuan berarti kapasitas seseorang individu untuk melakukan beragam tugas dalam suatu pekerjaan.” Lebih lanjut Robbin (2006:46) menyatakan bahwa, "Kemampuan (ability) adalah sebuah penilaian terkini atas apa yang dapat dilakukan seseorang.” Berdasarkan pengertian tersebut dapat disimpulkan bahawa kemampuan (ability) adalah kecakapan atau potensi seseorang individu untuk menguasai keahlian dalam melakukan atau mengerjakan beragam tugas dalam suatu pekerjaan atau suatu penilaian atas tindakan seseorang.

Suriasumantri (2009:42) menyatakan bahwa, "Penalaran merupakan suatu proses berpikir dalam menarik suatu kesimpulan yang berupa pengetahuan dan mempunyai karakteristik tertentu dalam menemukan kebenaran.” Dia juga menambahkan sebagai suatu kegiatan berpikir maka penalaran mempunyai ciri-ciri tertentu. Ciri yang pertama ialah adanya suatu pola berpikir yang secara luas dapat disebut logika, ciri yang kedua ialah sifat analitik dari proses berpikirnya, kegiatan berpikir berdasarkan langkah-langkah tertentu. "Penalaran adalah suatu kegiatan berpikir khusus, dimana terjadi suatu penarikan kesimpulan, dimana pernyataan disimpulkan dari beberapa premis”, (Shodiq, 2005:47). Ada dua penalaran yang dipergunakan orang untuk menarik sebuah kesimpulan datau membuat suatu keputusan, yakni pola penalaran induktif dan pola penalaran deduktif.

Penalaran induktif merupakan cara berpikir dimana ditarik suatu kesimpulan yang bersifat umum dari berbagai kasus yang bersifat individual. Kebenaran pendapat induktif ditentukan secara mutlak oleh kebenaran fakta (Soekadijo, 2008:132). Penalaran deduktif merupakan cara berpikir dimana dari pernyataan umum ditarik kesimpulan yang bersifat khusus, penarikan kesimpulan menggunakan silogisme (kontruksi penalaran). Silogisme terdiri atas kalimatkalimat pernyataan yang dalam penalaran/logika disebut proposisi. Proposisiproposisi yang menjadi dasar penyimpulan disebut premis, sedangkan kesimpulannya disebut konklusi. Silogisme berfungsi sebagai proses pembuktian benar-salahnya suatu pendapat, tesis atau hipotesis tentang masalah tertentu. Deduksi berpangkal dari suatu pendapat umum berupa teori, hokum atau kaedah dalam menyusun suatu penjelasan tentang suatu kejadian khusus (Sa'adah, 2010:14).

Suriasumantri (2009:193) mengatakan bahwa, "Matematika mempunyai kelebihan lain dibandingkan dengan bahasa verbal. Matematika mengembangkan bahasa numerik yang memungkinkan kita melakukan pengukuran secara kuantitatif." Hampir sama dengan pendapat di atas, Hudoyo (2005:123) menyatakan bahwa, "Matematika merupakan ide-ide abstrak yang diberi simbol- 
simbol itu tersusun secara hirarkis dan penalarannya deduktif, sehingga belajar matematika itu merupakan kegiatan mental yang tinggi.”

Dari uraian teori di atas, maka dapat ditarik kesimpulan bahwa kemampuan penalaran matematika adalah kemampuan berpikir berdasarkan langkah-langkah tertentu dalam menarik suatu kesimpulan dari konsep atau pemahaman yang didapat sebelumnya. Siswa yang mempunyai kemampuan penalaran tinggi antara lain tampak dari kemampuan berpikir secara logis, baik yang bersifat deduktif maupun induktif. Siswa mampu berpikir analitik, yaitu, suatu kegiatan berpikir berdasarkan langkah-langkah tertentu. Siswa mampu membuktikan teorema tertentu serta mampu menarik kesimpulan berdasarkan langkah-langkah yang benar, misalnya dengan induksi matematik. Siswa yang mempunyai kemampuan penalaran tinggi juga mampu menghubungkan benda nyata, gambar maupun soal-soal cerita ke dalam ide matematika dan menjelaskan ide matematika baik lisan maupun tulisan.

\section{Kecemasan Belajar}

Oltmanns (2013:192) mengemukakan bahwa, “Anxiety (kecemasan) dapat merujuk pada suatu suasana, perasaan atau sindrom, ditandai dengan rasa ketakutan (fear) terhadap bahaya atau ancaman." Selanjutnya, dia menambahkan bahwa intensitas ketakutan biasanya meningkat. Hal tersebut membantu mengorganisasikan respon seseorang untuk menghindar atau melawan ancaman yang dia hadapi.

Kecemasan menurut Djiwandono (2009:387) dijelaskan sebagai berikut: Kecemasan ada dua, yaitu pertama, trait anxiety (sifat kecemasan), yaitu seorang yang mempunyai kecenderungan untuk menjadi cemas atau khawatir barangkali lebih banyak merespon terhadap banyak bentuk situasi, dengan telapak tangan yang berkeringat, dengan jantung yang berdetak keras. Individu dengan sifatsifat ini pada umumnya mengalami kecemasan dalam situasi yang lebih luas dan merasa cemasnya lebih sensitif daripada orang lain. Kedua, State anxiety (pernyataan cemas), yaitu kecemasan yang terjadi ketika seseorang mendapat ancaman tertentu. Jadi seseorang yang tidak cemas mungkin menjadi cemas jika dibawah ancaman tertentu.

Slameto (2010:2) mengatakan bahwa, "Belajar adalah suatu proses usaha yang dilakukan seseorang untuk memperoleh suatu perubahan tingkah laku yang baru secara keseluruhan, sebagai hasil pengalamannya sendiri dalam interaksi dengan lingkungannya." Thorndike dalam Djiwandono (2009:126), teorinya dikenal sebagai connectionism (pertautan, pertalian) karena dia berpendapat bahwa belajar adalah suatu proses "stamping in" (diingat), forming, hubungan antara Stimulus dan Respon. Thorndike menyatakan bahwa belajar adalah pembentukan hubungan atau koneksi antara stimulus dan respon dan penyelesaian masalah (problem solving) yang dapat dilakukan dengan cara trial and error (coba-coba).

Dari uraian di atas dapat diambil kesimpulan bahwa kecemasan belajar adalah perasaan cemas saat seseorang belajar yang timbul karena adanya tekanan dan ketidakmampuan menghadapi masalah. Kecemasan siswa dalam belajar dicirikan dengan kegelisahan, kekhawatiran, ketakutan yang tidak mendasar 
bahwa akan terjadi hal-hal yang tidak diinginkan. Gejala yang timbul saat siswa mengalami kecemasan belajar Matematika yaitu, 1) Gejala fisik seperti tegang saat mengerjakan soal Matematika, gugup, berkeringat, tangan gemetar, detak jantung meningkat, sakit kepala. 2) Gejala kognitif seperti pesimis dirinya tidak mampu mengerjakan soal Matematika, khawatir jika hasil pekerjaan matematikanya buruk. 3) Gejala perilaku seperti berdiam diri karena takut ditertawakan, tidak mau mengerjakan soal Matematika karena takut gagal, menghindari pelajaran Matematika, gangguan tidur, nafsu makan berkurang jika ada pekerjaan rumah pelajaran Matematika.

\section{Pemahaman Konsep Matematika}

Menurut Purwanto (2009:44), "Pemahaman adalah tingkat kemampuan yang mengharapkan testee (responden) mampu memahami arti atau konsep, situasi serta fakta yang diketahuinya.” Dalam hal ini testee tidak hanya hafal secara verbalitas, tetapi memahami konsep dari masalah atau fakta yang ditanyakan.

Perkins dalam Uno (2009:172) menyatakan bahwa, "Pemahaman menunjuk pada apa yang dapat seseorang lakukan dengan informasi itu dari apa yang telah mereka ingat." Indikator pemahaman yang siswa miliki, yaitu ketika siswa mengerti sesuatu, mereka dapat menjelaskan konsep-konsep dalam kalimat sendiri, menggunakan informasi dengan tepat dalam konteks baru, membuat analogi baru, dan generalisasi. Penghafalan dan pembacaan tidak menunjukkan pemahaman.

"Konsep menunjuk pada pemahaman dasar. Siswa mengembangkan suatu konsep ketika mereka mampu mengklasifikasikan atau mengelompokkan bendabenda atau ketika mereka dapat mengasosiasikan suatu nama dengan kelompok benda tertentu”, (Abdurrahman, 2012:204). Menurut Hamalik (2008:166) untuk mengetahui apakah siswa telah mengetahui dan memahami suatu konsep, paling tidak ada 4 hal yang telah diperbuatnya yaitu sebagai berikut: 1) ia dapat menyebutkan nama contoh-contoh konsep bila dia melihatnya, 2) ia dapat menyatakan ciri-ciri konsep itu, 3) ia dapat memilih, membedakan antara contohcontoh dari yang bukan contoh, 4) ia mungkin lebih mampu memecahkan yang berkenaan dengan konsep.

Berdasarkan uraian di atas maka disimpulkan bahwa pemahaman konsep matematika adalah Pemahaman konsep matematika adalah kemampuan pemahaman dasar seseorang dalam memahami berbagai konsep dalam matematika, kemudian mampu menngungkapkan kembali dalam bentuk lain yang mudah dimengerti dan mampu mengaplikasikan konsep tersebut.

\section{METODE}

Penelitian ini merupakan penelitian survey dengan pendekatan kuantitatif, dimana peneliti menggambarkan fenomena yang terjadi berdasarkan data yang diambil dari responden menggunakan instrument yang telah divalidasi sebelumnya. Desain penelitian yang digunakan adalah analisis jalur yaitu desain penelitian yang dilakukan jika antara variabel $\mathrm{X}_{1}$ dan $\mathrm{X}_{2}$ terdapat hubungan atau dengan kata lain terdapat varabel intervening yaitu $\mathrm{X}_{2}$ pada penelitian tersebut. 
Desain penelitian ini digunakan untuk mengetahui ada tidaknya pengaruh antara ketiga variabel tersebut secara langsung maupun tidak langsung. Konstelasi masalah penelitian ini sebagai berikut:

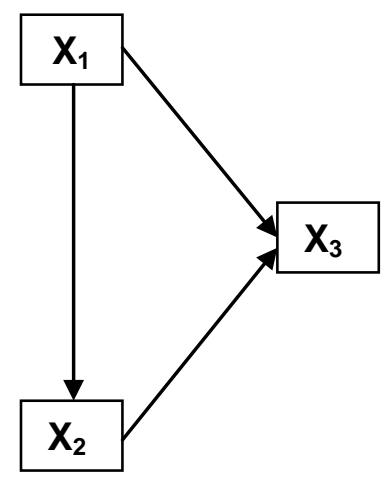

Gambar 1. Konstelasi Masalah

Keterangan:

$\mathrm{X}_{1}$ : Kecemasan belajar

$\mathrm{X}_{2}$ : Pemahaman konsep matematika

$\mathrm{X}_{3}$ : Kemampuan penalaran matematika

\section{HASIL DAN PEMBAHASAN}

\section{Analisis Deskriptif}

Skor kecemasan belajar yang diperoleh dari para responden mempunyai skor terendah 79, nilai tertinggi 144 , skor rata-rata sebesar 97,99, median sebesar 99, modus sebesar 98, dan simpangan baku sebesar 7,953. Nilai rata-rata dan median hampir sama yaitu 97,99 dan 99, hal ini menunjukkan bahwa kecemasan belajar pada penelitian ini cukup representatif. Sedangkan kecemasan belajar yang berada di atas rata-rata lebih banyak dibandingkan yang berada di bawah rata-rata menunjukkan bahwa siswa yang mempunyai kecemasan belajar yang lebih tinggi lebih banyak daripada yang rendah. Angka simpangan baku sebesar 7,953 atau sama dengan $8,12 \%$ dari rata-rata, menunjukkan perbedaan kemampuan penalaran matematika antar responden termasuk rendah. Hal ini menunjukkan bahwa kecemasan belajar dari responden tidak banyak beragam.

Data pemahaman konsep matematika yang diperoleh dari para responden mempunyai nilai terendah 32 , nilai tertinggi 92 , nilai rata-rata sebesar 62,90 median sebesar 64, modus sebesar 60, dan simpangan baku sebesar 12,126. Nilai rata-rata dan median hampir sama yaitu 97,99 dan 99. hal ini menunjukkan bahwa pemahaman konsep matematika pada penelitian ini cukup representatif. Sedangkan pemahaman konsep matematika yang berada di atas rata-rata lebih banyak dibandingkan yang berada di bawah rata-rata menunjukkan bahwa siswa yang mempunyai pemahaman konsep matematika yang lebih tinggi lebih banyak daripada yang rendah. Angka simpangan baku sebesar 7,953 atau sama dengan $8,12 \%$ dari rata-rata, menunjukkan perbedaan kemampuan penalaran matematika antar responden termasuk rendah. Hal ini menunjukkan bahwa kecemasan belajar dari responden tidak banyak beragam.

Data Penalaran Matematika yang diperoleh dari para responden yang terdiri dari 10 soal essay yang dijawab oleh 80 orang responden. Nilai yang diperoleh adalah nilai terendah 31, nilai tertinggi 98, nilai rata-rata sebesar 61,41, 
median sebesar 65 , modus sebesar 70 , dan simpangan baku sebesar 12,943 . Nilai rata-rata dan median mempunyai selisih yang kecil atau hampir sama yaitu 61,41 dan 65. Hal ini menunjukkan bahwa kemampuan penalaran matematika pada penelitian ini yang berada di atas rata-rata lebih banyak dibandingkan yang berada di bawah rata-rata menunjukkan bahwa siswa yang mempunyai kemampuan penalaran matematika yang lebih tinggi lebih banyak daripada yang rendah. Angka simpangan baku sebesar 12,943 atau sama dengan 21,08\% dari rata-rata, menunjukkan perbedaan kemampuan penalaran matematika antar responden termasuk rendah.

\section{Pengujian Persyaratan Analisis}

Hasil pengujian dengan menggunakan SPSS 20 diperoleh hasil sebagia berikut: variabel kecemasan belajar nilai Kolmogorov Smirnov $=1,235$ dengan probabilitas =0,94 (Asymp. Sig. (2-tailed)), variabel pemahaman konsep matematika nilai Kolmogorov Smirnov $=1,005$ dengan probabilitas $=0,215$ (Asymp. Sig. (2-tailed)), dan variabel penalaran matematika nilai Kolmogorov Smirnov $=1,195$ dengan probabilitas $=0,115$ (Asymp. Sig. (2-tailed)).

Menurut ketentuan yang ada pada program SPSS 20 maka kriteria dari normalitas adalah "jika $p$ value (sig) $>0,05$ berarti data pada sampel tesebut berdistribusi normal”. Dari data yang diperoleh menunjukkan bahwa nilai $p$ value (sig) > 0,05 maka ketiga variabel berdistribusi normal.

Uji linieritas dilakukan untuk mengetahui, membuktikan bahwa hubungan antar variabel yang diteliti memiliki hubungan yang linear. Dalam melakukan uji linear regresi antar variabel, peneliti malakukan analisis regresi dengan bantuan SPSS 20 dengan hasil sebagai berikut : Kecemasan Belajar dengan Kemampuan Penalaran Matematika menghasilkan nilai $\mathbf{F}=\mathbf{1 , 2 6 0}$ dengan nilai probabilitas (kolom sig) $\boldsymbol{p}=\mathbf{0 , 2 3 5}$. Kecemasan Belajar dengan Pemahaman Konsep Matematika menghasilkan nilai $\mathbf{F}=\mathbf{0 , 8 4 7}$ dengan nilai probabilitas (kolom sig) $\boldsymbol{p}=\mathbf{0 , 6 7 4}$. Pemahaman Konsep Matematika dengan Kemampuan Penalaran Matematika menghasilkan nilai $\mathbf{F}=\mathbf{0 , 7 7 6}$ dengan nilai probabilitas (kolom sig) $\boldsymbol{p}=\mathbf{0 , 6 8 1}$. Jika nilai probabilitas $p>0,05$ maka artinya model regresi bersifat linear, berdasarkan data yang diperoleh hubungan anatar variabel memiliki nilai $p>0,05$, dengan demikian dapat disimpulkan model regresi bersifat linier.

Berdasarkan pengolahan data dengan SPSS menunjukkan nilai VIF sebesar 1,001 di sekitar angka 1. Tolerance yang diperoleh sebesar 0,999 mendekati angka 1, maka terdapat dugaan bebas dari adanya kolinieritas antara kecemasan belajar dengan pemahamn konsep matematika.

\section{Pengujian Hipotesis Penelitian}

Pengujian hubungan antar variabel penelitian menggunkan analisis jalur (Path Analysis). 


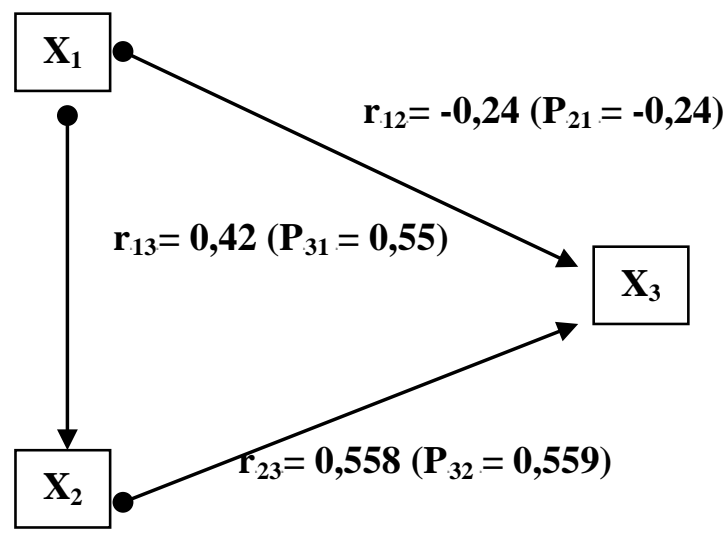

\section{Gambar 2. Diagram Koefisien Korelasi dan Koefisien Jalur}

\section{Pengujian hipotesis 1}

Nilai Sig. 0,559 dan $t_{\text {hitung }}=0,587$, sedangkan $t_{\text {tabel }}=1,994$. Karena nilai Sig. $>0,05$ dan nilai $t_{\text {hitung }}<t_{\text {tabel }}$ berarti tidak terdapat pengaruh langsung antara variabel kecemasan belajar $\left(\mathrm{X}_{1}\right)$ terhadap kemampuan penalaran matematika $\left(\mathrm{X}_{3}\right)$.

2. Pengujian hipotesis 2

Nilai Sig. 0,000 dan $t_{\text {hitung }}=5,924$, sedangkan $t_{\text {tabel }}=1,994$. Karena nilai Sig. $<$ 0,05 dan nilai $t_{\text {hitung }}>t_{\text {tabel }}$ berarti terdapat pengaruh langsung antara variabel pemahaman konsep matematika $\left(\mathrm{X}_{2}\right)$ terhadap kemampuan penalaran matematika $\left(\mathrm{X}_{3}\right)$.

3. Pengujian hipotesis 3

Nilai Sig. 0,831 dan $t_{\text {hitung }}=-0,215$, sedangkan $t_{\text {tabel }}=1,994$. Karena nilai Sig. $>$ 0,05 dan nilai $t_{\text {hitung }}<\mathrm{t}_{\text {tabel }}$ maka berarti tidak terdapat pengaruh langsung antara variabel kecemasan belajar $\left(\mathrm{X}_{1}\right)$ terhadap pemahaman konsep matematika $\left(\mathrm{X}_{2}\right)$.

4. Pengujian hipotesis 4

Dari perhitungan menggunakan Ms Excel didapatkan $t_{\text {hitung }}(1,288)<t_{\text {tabel }}(1,994)$ yang berarti tidak terdapat pengaruh tidak langsung antara kecemasan belajar $\left(\mathrm{X}_{1}\right)$ terhadap kemampuan penalaran matematika $\left(\mathrm{X}_{3}\right)$ melalui pemahaman konsep matematika $\left(\mathrm{X}_{2}\right)$.

\section{Pembahasan}

\section{Pengaruh Langsung Kecemasan Belajar terhadap Kemampuan Penalaran} Matematika

Berdasarkan analisis data SPSS 20.0 dapat diketahui persamaan regresi $\widehat{\mathrm{X}}_{3}=0,55 \mathrm{X}_{1}+$ $0,559 \mathrm{X}_{2}$. Yang berarti bahwa koefisien regresi kecemasan belajar sebesar 0,55 memberikan pemahaman bahwa setiap penambahan satu satuan atau satu tingkatan kecemasan belajar berdampak pada meningkatnya kemampuan penalaran matematika sebesar 0,55. Maran (2007:80) mengatakan bahwa, ” Penalaran adalah suatu proses mental yang bergerak dari apa yang kita ketahui kepada apa yang kita ketahui sebelumnya”. Proses berpikir kita bergerak dari pengetahuan yang sudah kita miliki tentang sesuatu yang ada menuju pengetahuan baru yang terkait dengannya. Penalaran adalah proses berpikir dalam menarik suatu kesimpulan dari konsep yang didapat 
sebelumnya, yang bercirikan pada logika dan analitik dari proses berpikirnya, kegiatan berpikir berdasarkan langkah-langkah tertentu.

Oltmanns (2013:192) mengemukakan bahwa, “Anxiety (kecemasan) dapat merujuk pada suatu suasana, perasaan atau sindrom, ditandai dengan rasa ketakutan (fear) terhadap bahaya atau ancaman.” Perasaan cemas timbul ketika seseorang mengalami tekanan perasaan (frustasi) serta ketidakmampuan menghadapi masalah. Perasaan cemas biasanya diikuti oleh reaksi fisiologis tertentu yaitu seperti perubahan detak jantung dan pernapasan.

Dari data di atas, dapat dikatakan bahwa apabila kemampuan penalaran matematika ingin ditingkatkan secara optimal, maka perlu mengurangi atau meminimalisir adanya perasaan cemas, khawatir, atau takut terhadap pelajaran Matematika saat belajar. Dapat disimpulkan bahwa kecemasan belajar berpengaruh langsung yang negative terhadap kemampuan penalaran matematika.

Berdasarkan hasil perhitungan di atas, maka hasil penelitian ini tidak sesuai dengan pengajuan hipotesis, yaitu bahwa tidak terdapat pengaruh langsung positif dan signifikan kecemasan belajar terhadap kemampuan penalaran matematika.

\section{Pengaruh Langsung Pemahaman Konsep Matematika Siswa Terhadap Kemampuan Penalaran Matematika}

Berdasarkan analisis data SPSS 20.0 dapat diketahui persamaan regresi $\widehat{\mathrm{X}}_{3}=0,55 \mathrm{X}_{1}+$ $0,559 \mathrm{X}_{2}$. Yang berarti bahwa koefisien regresi pemahaman konsep matematika sebesar 0,59 memberikan pemahaman bahwa setiap penambahan satu satuan atau satu tingkatan pemahaman konsep matematika berdampak pada meningkatnya kemampuan penalaran matematika sebesar 0,559. Pemahaman konsep merupakan dasar dari pemahaman prinsip dan teori teori, sehingga untuk memahami prinsip dan teori terlebih dahulu siswa harus memahami konsep-konsep yang menyusun prinsip dan teori tersebut. Karena itu hal yang sangat fatal apabila siswa tidak memahami konsep-konsep matematika, jika mereka ingin menguasai matematika khususnya kemampuan berpikir tingkat tinggi siswa antara lain penalaran matematika. Kemampuan penalaran matematika adalah kemampuan berpikir berdasarkan langkah-langkah tertentu dalam menarik suatu kesimpulan dari konsep atau pemahaman yang didapat sebelumnya. Jika pemahaman konsep matematika siswa baik maka kemampuan penalaran matematika juga baik, sebaliknya jika pemahaman konsep matematika siswa kurang maka dalam penalaran matematika pun mereka akan mengalami kesulitan. Berdasarkan hasil perhitungan di atas, maka hasil penelitian ini sesuai dengan pengajuan hipotesis, yaitu terdapat pengaruh langsung positif yang signifikan pemahaman konsep matematika terhadap kemampuan penalaran matematika.

\section{Pengaruh Langsung Kecemasan Belajar terhadap Pemahaman Konsep Matematika Siswa}

Beradasarkan analisis data SPSS 20.0 dapat diketahui persamaan regresi $\widehat{X}_{2}=-0,24 \mathrm{X}_{1}$. Yang berarti bahwa koefisien regresi kecemasan belajar sebesar -0,24 memberikan pemahaman bahwa setiap satu satuan atau satu tingkatan kecemasan belajar akan berdampak berkurangnya pemahamn konsep matematika sebesar 0,24.

Menurut Purwanto (2009:44), "Pemahaman adalah tingkat kemampuan yang mengharapkan testee (responden) mampu memahami arti atau konsep, situasi serta fakta yang diketahuinya." Dalam hal ini testee tidak hanya hafal secara verbalitas, tetapi memahami konsep dari masalah atau fakta yang ditanyakan. Jadi seseorang dikatakan paham terhadap sesuatu bila orsng tersebut mampu menjelaskan dengan kalimat sendiri hal yang diketahuinya. "Konsep menunjuk pada pemahaman dasar. Siswa mengembangkan suatu konsep ketika mereka mampu mengklasifikasikan atau 
mengelompokkan benda-benda atau ketika mereka dapat mengasosiasikan suatu nama dengan kelompok benda tertentu”, (Abdurrahman, 2012:204). Pemahaman konsep matematika adalah kemampuan pemahaman dasar seseorang dalam memahami berbagai konsep dalam matematika, kemudian mampu menngungkapkan kembali dalam bentuk lain yang mudah dimengerti dan mampu mengaplikasikan konsep tersebut.

Kecemasan merupakan salah satu alasan mengapa hubungan interpersonal yang baik penting dalam memahami matematika. Kecemasan dapat meningkat, bersifat subjektif pada setiap individu, dan memengaruhi sulit atau tidaknya pemahaman, karena tingkat pemahaman antar siswa berbeda, ada siswa yang dapat dengan mudah memahami ketika menerima penjelasan, tetapi ada siswa yang harus berulang kali dijelaskan baru paham.

Dari uraian di atas dapat dikatakan bahwa, untuk meningkatkan pemahaman konsep matematika siswa, maka salah satunya siswa harus mampu mengurangi perasaan cemas dari dalam diri mereka serta guru juga mampu menciptakan suasana yang menyenangkan sehingga siswa tidak merasa tegang atau khawatir saat mengikuti pelajaran Matematika.

Berdasarkkan hasil penelitian di atas, maka hasil penelitian ini sejalan dengan pengajuan hipotesis peneliti bahwa terdapat pengaruh langsung yang negative kecemasan belajar terhadap pemahaman konsep matematika.

\section{Pengaruh Tidak Langsung Kecemasan Belajar terhadap Kemamapuan Penalaran Matematika melalui Pemahamn Konsep Matematika Siswa}

Berdasarkan hasil perhitungan diperoleh $\mathrm{t}_{\text {hitung }}=1,288<\mathrm{t}_{\text {tabel }}=1,994$ maka hasil penelitian ini tidak sesuai dengan pengajuan hipotesis yaitu tidak terdapat pengaruh tidak langsung antara kecemasan belajar terhadap kemampuan penalaran matematika melalui pemahaman konsep matematika.

Berdasarkan temuan penelitian ini menunjukkan peningkatan kemampuan penalaran matematika dapat dilakukan dengan peningkatan pemahaman konsep matematika. Peningkatan pemahaman konsep matematika dapat guru lakukan dengan cara merancang pembelajaran dengan baik, pembelajaran yang mampu membantu siswa membangun pemahamannya secara bermakna. Dari pembelajaran yang menyenangkan maka akan menimbulkan ketertarikan siswa kepada materi yang sednag dipelajari, suasana yang kondusif juga memberikan kenyamanan belajar bagi siswa sehingga kecemasan atau kekhawatiran yang sering timbul dalam diri siswa bisa berkurang.

Penelitian ini berhasil menemukan bahwa kecemasan belajar yang berlebihan berpengaruh positif dan negatif terhadap pemahaman siswa dalam belajar. Siswa yang mampu mengendalikan kecemasannya akan menjadi lebih semangat dalam belajar karena siswa tersebut khawatir jika hasil belajarnya tidak baik artinya kecemasan berpengaruh positif. Sedangkan siswa yang tidak mampu mengendalikan kecemasan dalam dirinya dapat membuat siswa tersebut semakin cemas sehingga tersebut putus asa.

\section{PENUTUP \\ Simpulan}

Berdasarkan pengolahan data pada bab IV, dihasilkan beberapa temuan yang dapat peneliti simpulkan sebagai berikut:

1. Terdapat pengaruh langsung yang tidak signifikan kecemasan belajar $\left(\mathrm{X}_{1}\right)$ terhadap kemampuan penalaran matematika $\left(\mathrm{X}_{3}\right)$ hal tersebut dibuktikan oleh nilai Sig. 0,559 dan $t_{\text {hitung }}=0,587$, sedangkan $t_{\text {tabel }}=1,994$. Karena nilai Sig. $>0,05$ dan nilai $t_{\text {hitung }}<t_{\text {tabel }}$ maka $\mathrm{H}_{0}$ diterima berarti terdapat pengaruh langsung yang tidak signifikan kecemasan belajar $\left(\mathrm{X}_{1}\right)$ terhadap kemampuan penalaran matematika $\left(\mathrm{X}_{3}\right)$. 
2. Terdapat pengaruh langsung yang signifikan pemahaman konsep matematika $\left(\mathrm{X}_{2}\right)$ terhadap kemampuan penalaran matematika $\left(\mathrm{X}_{3}\right)$, hal tersebut dibuktikan oleh nilai Sig. 0,000 dan $t_{\text {hitung }}=5,924$, sedangkan $t_{\text {tabel }}=1,994$. Karena nilai Sig. $<0,05$ dan nilai $t_{\text {hitung. }}$ $>\mathrm{t}_{\text {tabel }}$ maka $\mathrm{H}_{0}$ ditolak berarti terdapat pengaruh langsung yang signifikan pemahaman konsep matematika $\left(\mathrm{X}_{2}\right)$ terhadap kemampuan penalaran matematika $\left(\mathrm{X}_{3}\right)$.

3. Terdapat pengaruh langsung yang tidak signifikan kecemasan belajar $\left(\mathrm{X}_{1}\right)$ terhadap pemahaman konsep matematika $\left(\mathrm{X}_{2}\right)$ hal tersebut dibuktikan oleh nilai Sig. 0,831 dan $\mathrm{t}_{\text {hitung. }}=-0,215$, sedangkan $\mathrm{t}_{\text {tabel }}=1,994$. Karena nilai Sig. $>0,05$ dan nilai $\mathrm{t}_{\text {hitung }}<\mathrm{t}_{\text {tabel }}$ maka $\mathrm{H}_{0}$ diterima berarti terdapat pengaruh langsung yang tidak signifikan kecemasan belajar $\left(\mathrm{X}_{1}\right)$ terhadap pemahaman konsep matematika $\left(\mathrm{X}_{2}\right)$.

4. Terdapat pengaruh tidak langsung yang tidak signifikan kecemasan belajar $\left(\mathrm{X}_{1}\right)$ terhadap kemampuan penalaran matematika $\left(\mathrm{X}_{3}\right)$ melalui pemahaman konsep matematika $\left(\mathrm{X}_{2}\right)$ hal tersebut dibuktikan oleh nilai $\mathrm{t}_{\text {hitung }}(1,288)<\mathrm{t}_{\text {tabel }}(1,994)$ maka $\mathrm{H}_{0}$ diterima yang berarti terdapat pengaruh tidak langsung yang tidak signifikan kecemasan belajar $\left(\mathrm{X}_{1}\right)$ terhadap kemampuan penalaran matematika $\left(\mathrm{X}_{3}\right)$ melalui pemahaman konsep matematika $\left(\mathrm{X}_{2}\right)$.

\section{Saran}

Berdasarkan hasil penelitian dan simpulan, dikemukan beberapa saran sebagai berikut:

a. Banyak hal yang dapat dilakukan untuk meningkatkan kemampuan penalaran matematika siswa, diantaranya dengan meningkatkan pemahaman konsep matematika siswa. Hal ini dibuktikan dengan hasil penelitian di atas. Oleh karena itu, sebaiknya guru harus menekankan pemahaman konsep matematika siswa sebelum melanjutkan ke materi yang lebih tinggi.

b. Pemahaman konsep matematika dipengaruhi oleh banyak faktor, diantaranya adalah kecemasan belajar. Kecemasan belajar berpengaruh negatif terhadap pemahaman konsep matematika siswa. Hal ini dibuktikan dengan hasil penelitian di atas. Oleh karena itu sebaiknya guru harus mampu meciptakan suasana belajar yang kondusif, menyenagkan serta tanpa tekanan, sehingga dapat mengurangi kecemasan belajar siswa.

c. Dalam melakukan sesuatu seseorang butuh penghargaan yang dapat membangkitkan semangat untuk melakukan hal tersebut. Oleh karena itu sebaiknya guru sering-seringlah memberikan motivasi dan penghargaan walaupun pengehargaan tersebut hanya berupa pujian.

\section{DAFTAR PUSTAKA}

Abdurrahman, Mulyono. 2012. Anak Berkesulitan Belajar Teori, Diagnosis, dan Remediasinya. Jakarta: Rineka Cipta.

Aqib, Zaenal. 2013. Konseling Kesehatan Mental Untuk Mahasiswa, Guru, Konselor, Dosen. Bandung: Yrama Widya.

Djiwandono, Sri Esti Wuryani. 2009. Psikologi Pendidikan. Jakarta: PT Grasindo.

Hamalik, Oemar. 2008. Perencanaan Pangajaran Berdasarkan Pendekatan Sistem. Jakarta: Bumi Aksara.

Hudoyo, Herman. 2005. Pengembangan Kurikulum dan Pembelajaran Matematika. Malang : FMIPA.

Maran, Rafael Raga. 2007. Pengantar Logika. Jakarta: Grasindo. 
Oltmanns, Thomas S. 2013. Psikologi Abnormal. Yogyakarta: Pustaka Jaya.

Purwanto, Ngalim. 2009. Prinsip-prinsip Dan Teknik Evaluasi Pengajaran. Bandung: PT Remaja Rosdakarya.

Robbins, Stephen P. 2006. Perilaku Organisasi. Jakarta: Salemba Empat.

Sa'adah, Widayanti Nurma. 2010. Peningkatan Kemampuan Penalaran Matematis Siswa Kelas VIII SMP Negeri 3 Banguntapan Dalam Pembelajaran Matematika Melalui Pendekatan Pendidikan Matematika Realistik Indonesia (PMRI). UNY: Skripsi. Tidak Dipublikasikan.

Shadiq, Fajar. 2005. Penalaran dan Komunikasi, dalam Tim PPPG Matematika, Materi Pembinaan Matematika SMP di Daerah. Yogyakarta: Depdiknas.

Slameto. 2010. Belajar Dan Faktor-Faktor Yang Mempengaruhinya. Jakarta: Rineka Cipta.

Soekadijo. 2008. Logika Dasar Tradisional, Simbolik dan Induktif. Jakarta: PT Gramedia.

Suriasumantri, Jujun S. 2009. Filsafat Ilmu Sebuah Pengantar Populer. Jakarta: Pustaka Sinar Harapan.

U.S., Supardi. 2012. Aplikasi Statistika Dalam Penelitian. Jakarta: PT Ufuk Publishing House.

Uno, Hamzah B. dan Masri Kuadrat. 2009. Mengelola Kecerdasan Dalam Pembelajaran Sebuah Konsep Pembelajaran Berbasis Kecerdasan. Jakarta: PT Bumi Aksara. 